\title{
THE RELATION BETWEEN DRIVER BEHAVIOR AND INTELLIGENT TRANSPORT SYSTEM
}

\author{
Alica Kalašováa, ${ }^{a, *}$ Simona Kubíková ${ }^{b}$, JÁn Kapusta ${ }^{b}$ \\ ${ }^{a}$ Univerzitná 1,Âă010 26, Žilina, Slovak Republic, Supervisor of Department of Road and Urban Transport \\ ${ }^{b}$ Univerzitná 1,Âă010 26, Žilina, Slovak Republic, PhD. Student \\ * corresponding author: alica.kalasova@fpedas.uniza.sk
}

\begin{abstract}
The main objective of Slovakia's transport policy is to reduce the number of traffic accidents and increase safety on our roads. Implementation of intelligent transport systems presents one of the possibilities how to meet this goal. Acceptance of these systems by motor vehicle drivers and other road traffic participants is necessary in order for them to fulfill their purpose. Only if the drivers will accept intelligent transport systems, it is possible to flexibly and effectively manage road traffic flexibly and effectively. From the perspective of a driver it concerns, in particular, the possibility of using alternative routes when traffic accidents or other obstacles occurs on the route that would significantly affect the continuity and safety of road traffic. Thanks to these technologies, it is possible to choose the appropriate route while driving, of course based on the criterion, which the driver considers the most important during the transport from origin to destination (driving time, distance from origin to destination, fuel consumption, quality of infrastructure). Information isare provided to the driver through variable message signs or directly in the vehicle (RDS-TMC). Another advantage of intelligent transport systems is a positive impact on psychological well-being of the driver while driving. Additional information about the possible obstacles, weather conditions and dangerous situations that occur on the roads as well as alternative routes are provided to the driver well in advance.

This paper is mainly focused on how the drivers perceive the influence of intelligent transport systems in Žilina region.
\end{abstract}

KEYWORDS: Safety, accidents, ITS.

\section{INTRODUCTION}

The Slovak Republic has implemented into its legislation aÂ̆alegally binding act of the European Union, Directive 2010/40/EU of the European Parliament and of the Council of 7 July 2010 on the framework for the deployment of intelligent transport systems in the field of road transport and for interfaces with other modes of transport. Thereby, the Slovak Republic committed to meet the conditions of implementation and use of intelligent transport systems. However, effort exists to improve this situation through the adoption of Act No. 317/2012 Coll. on intelligent transport systems in road transport and amending and supplementing certain acts, as well as by adopting National Road Safety Plan of the Slovak Republic in the years 2011-2020 and Program to support the development of Intelligent Transport Systems and National System of Traffic Information.

The basis of these documents is a promising creation of a so-called vision of zero accident rate in the field of transport safety. In this context that regarding the European area of road traffic safety, the European Commission enforces reduction of the number of road traffic fatalities by half in comparison with 2010 as a priority for years 2011 to $2020[1]$.

In recent years, the Slovak Republic managed to lower the number of traffic accidents. The ambitious objective of Slovakia's commitment under the European Road Safety Charter to reduce the number of fatalities in road accidents to half by 2010, in comparison with 2002, when 610 people were killed on our roads, was not fulfilled. We managed to lower the number to 345 fatalities, which represents a $43 \%$ decrease. Even though we failed to meet the commitment mentioned above, subsequent statistical indicators of accident rates in the Slovak Republic, which show a downward trend, are positively perceived in Slovakia as well as in the European Union[2]. Figure 1 shows the decrease of accident rates on our roads from 2000 to 2015. This decrease is caused by the development and evolution of automotive technology (especially the development of active and passive safety of vehicles) as well as by better and more suitable roads, better traffic signs, proper traffic management and organizational measures and also by the use of intelligent transport systems. The rapid decline of accident rate between 2008 and 2009 was caused by the adoption of new laws and Decree in our legislative related to traffic safety[3].

This paper is focused mainly on the analysis of traffic situation in Žilina region, specifically on the section between the city of Bytča and Ivachnová village. The intensity of vehicles on this section is one of the highest in the region. The application of intelligent transport systems is one of the most effective 
Evolution of accident rates in the Slovak Republic

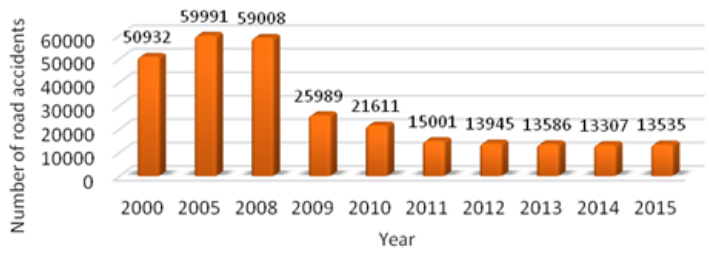

Figure 1. Evolution of accident rates in the Slovak Republic from 2000 to 2015 .

\begin{tabular}{|l|l|l|l|}
\hline City & $\begin{array}{l}\text { Road } \\
\text { name }\end{array}$ & Intensity & $\begin{array}{l}\text { Traffic } \\
\text { acci- } \\
\text { dents }\end{array}$ \\
\hline Ružomberok nad & D1 & 19636 & 3 \\
\hline $\begin{array}{l}\text { Hlboké } \\
\text { Váhom-Strečno }\end{array}$ & & 26087 & 86 \\
\hline Śútovo-Kralovany & $\mathrm{I} / 18$ & 21225 & 5 \\
\hline $\begin{array}{l}\text { Kralovany-Dolný } \\
\text { Kubín }\end{array}$ & $\mathrm{I} / 70$ & 13766 & 8 \\
\hline Vrútky-Kralovany & $\mathrm{I} / 18$ & 21758 & 33 \\
\hline Kralovany-Sliačé & $\mathrm{I} / 18$ & 21861 & 31 \\
\hline Żilina-Terchová & $\mathrm{II} / 583$ & 5366 & 39 \\
\hline Terchová-Párnica & $\mathrm{II} / 583$ & 3843 & 5 \\
\hline
\end{tabular}

TABLE 1. Traffic accident rates on the selected sections of road network in 2014.

ways how to improve traffic situation on this road section.

\section{Characteristic of the Selected Section of Road Network}

Selected section of road network consists of the first and second class roads and D1 motorway. The statistics of traffic accidents based on the section and type of road are listed in the following Table 1. Presented data are from 2014. The table shows that the most traffic accidents in 2014 on a selected road network were documented on the section from Hlboké nad Váhom to Strečno (road I/18), where the highest intensity of vehicles per 24 hours was also recorded.

\subsection{Measurement of Road Network SAFETY}

Indicators of accident rates usually determine the safety on roads. Safety is the result of risk and level of risk influence. The risk is expressed by the number of traffic accidents and the level of risk influence is specified through intensity. The indicators always refer to the same period of time, which is in this case one year. This enables us to determine the frequency of traffic accidents.

$$
\text { Frequency }=N / t
$$

where: $N$ - number of traffic accidents, $t$ - time period [year].

Relative accident rate represents the probability of occurrence of traffic accident on individual sections. It is calculated as the ratio between the number of traffic accidents and traffic performance. When calculating this indicator, it is necessary to distinguish whether it is a calculation of relative accident rate at intersections or on sections between intersections 4 .

$$
R=\frac{N}{365 * R P D I * t} * 10^{6}
$$

for intersections

$$
R=\frac{N}{365 * R P D I * L * t} * 10^{6}
$$

for sections

where: $N$ - number of traffic accidents, $R P D I-$ annual average of daily intensities, $t$ - time period, $L$ - length of examined section.

Another indicator that is used to assess safety is the density of traffic accidents. It refers to the number of road accidents and to the section length, thus intensity is not taken into account. It is calculated according to the formula:

$$
H=\frac{N}{L * t}
$$

where: $H$ - density of traffic accidents, $N$ - number of traffic accidents, $t$ - time period, $L$ - length of examined section.

Frequency of accidents, relative accident rate and density of accidents were the indicators used in this paper. These indicators were calculated based on the statistical data from 2014 and they are listed in Table 2]5, 6.

As shown in Table 2, relative accident rate which depends on the transport performance is not critical in any case. However, it should be noted that property damage only (PDO) accidents were not taken into account since these statistics were not available. Otherwise, the values of relative accident rate would be much higher. The highest value of density of traffic accidents ( 3,1 accidents per one kilometer) was recorded on the stretch from Hlboké nad Váhom to Strečno, which is the section of road I/18. Also in this case, property damage only accidents were not included in the calculation.

This analysis shows that it is necessary to solve the traffic situation on the given section mainly through long-term organizational measures as well as by the application of intelligent transport systems.

Voluntary acceptance of intelligent transport systems by drivers and other road traffic participants is necessary in order for it to be effective. A questionnaire survey, whose main goal was to identify the requirements and needs of road users as well as the level of perception of intelligent transport systems was conducted within the Žilina region. 


\begin{tabular}{|l|l|l|l|l|l|}
\hline Section & $\begin{array}{l}\text { RPDI } \\
\text { [veh/24] }\end{array}$ & L [km] & $\begin{array}{l}\text { N [num- } \\
\text { ber of ac- } \\
\text { cidents] }\end{array}$ & R [\%] & $\begin{array}{l}\text { H [number of acci- } \\
\text { dents/km/year] }\end{array}$ \\
\hline Ružomberok & 19636 & 3,06 & 3 & 13,67899 & 0,980392157 \\
\hline $\begin{array}{l}\text { Hlboké nad Váhom- } \\
\text { Strečno }\end{array}$ & 26087 & 27,7 & 86 & 32,60631 & 3,104693141 \\
\hline Sútovo-Kralovany & 21225 & 5,2 & 5 & 12,41155 & 0,961538462 \\
\hline $\begin{array}{l}\text { Kralovany-Dolný } \\
\text { Kubín }\end{array}$ & 13766 & 18,1 & 8 & 8,79652 & 0,44198895 \\
\hline Vrútky-Kralovany & 21758 & 15,7 & 33 & 26,46686 & 2,101910828 \\
\hline Kralovany-Sliače & 21861 & 27,2 & 31 & 14,28334 & 1,139705882 \\
\hline Žilina-Terchová & 5366 & 24,5 & 39 & 81,27463 & 1,591836735 \\
\hline Terchová-Párnica & 3843 & 20,4 & 5 & 17,47337 & 0,245098039 \\
\hline
\end{tabular}

TABle 2. Accident indicators.

\section{Analysis of Perception of InTELLIGENT TRANSPORT Systems FROM THE PERSPECTIVE OF DRIVERS}

The survey was conducted electronically through a website, as well as by personal conversations with residents who possess a valid driving license. Data was collected during one month, from April 13, 2015 to May 19, 2015. Subsequently, the data were was analyzed and evaluated graphically and in tables. The tool called ,"Sample Size Calculator" was used to determine the minimum sample size that is required for sufficient explanatory power of the survey, in which we set up the population of registered drivers in Žilina region to $414 \hat{A} a ̆ 678$, we chose $95 \%$ confidence interval and permissible margin of error was $5 \%$ (Fig. 2 ). The minimum sample was set to 384 respondents. A total of 519 respondents participated in the survey and therefore we can conclude, that the survey has sufficient explanatory power.

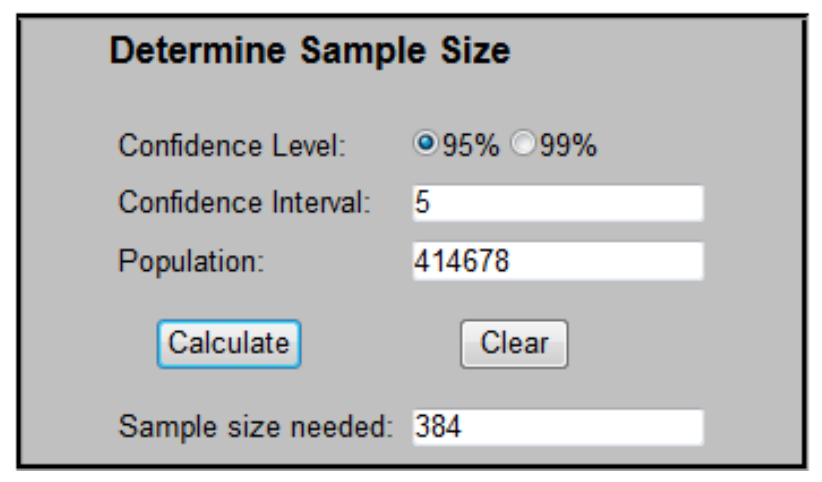

Figure 2. Sample size calculator.

The first part of the questionnaire was focused on the categorization of respondents according to age, sex and also according to the fact whether the respondent is an active or passive driver (Fig. 3).

The purpose and regularity of trips made during the week were also examined (Fig. 4).

When choosing the route, every driver prefers the

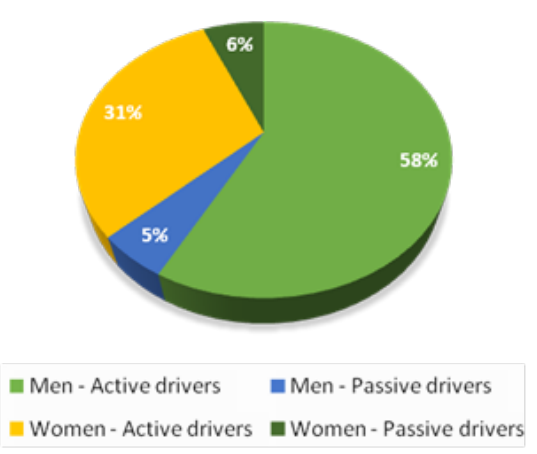

Figure 3. Percentage of active and passive drivers.

route that best suits his needs and criteria. Essential criteria for choosing the most appropriate route are fuel consumption, time accessibility of the destination point, distance between origin and destination, the danger of traffic accidents and so on. The evaluation scale was as follows: 0 - irrelevant, 1 - the least significant, 5 - the most important. Weighted arithmetic means of importance of the individual criteria are calculated from these values and they are graphically processed in Table 3 , which shows that the most important criterion for men in both age categories is the quality of transport infrastructure. Time accessibility of destination point is the most important for women.

Traffic congestions and delays on roads can be eliminated through the opportunity to use an alternative route, to which the vehicle will be diverted via information systems installed directly in the vehicle (RDS-TMC) or through information systems situated on roads that contain information for the entire traffic flow (variable message signs). In the questionnaire survey, respondents were also asked whether they would be willing to take an alternative route offered by the information system in case of traffic accident or the occurrence of other obstacles on their original route. The results are shown in Fig. 5

The most frequent answer of the respondents was that they are willing to accept an alternative route even if the distance to the destination would rise by 


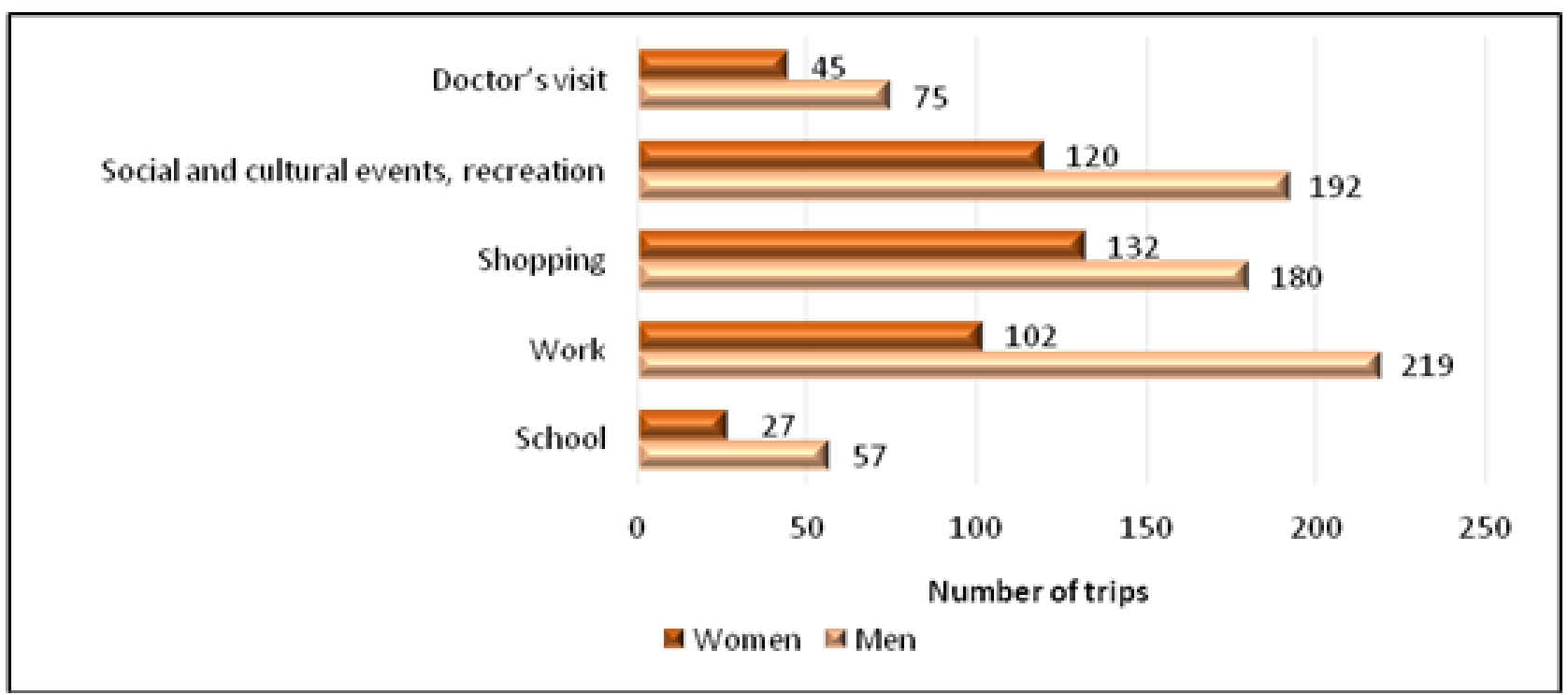

Figure 4. Purpose of transport and routing of traffic flows.

\begin{tabular}{|c|c|c|c|c|}
\hline Criteria & Men 18-26 & Men 27-65 & Women 18-26 & Women 27-65 \\
\hline Fuel consumption & 3,59 & 3,52 & 3,10 & 3,75 \\
\hline Travel time & 3,79 & 3,95 & 3,96 & 4,13 \\
\hline Distance between origin and destination & 3,27 & 3,39 & 3,40 & 3,75 \\
\hline Quality of road infrastructure & 3,80 & 3,97 & 3,90 & 4,13 \\
\hline Possibility of congestion & 3,48 & 3,66 & 3,42 & 3,50 \\
\hline Possibility of road accident & 3,23 & 2,71 & 3,52 & 3,69 \\
\hline
\end{tabular}

TABLE 3. Criteria for route selection - weighted arithmetic mean.
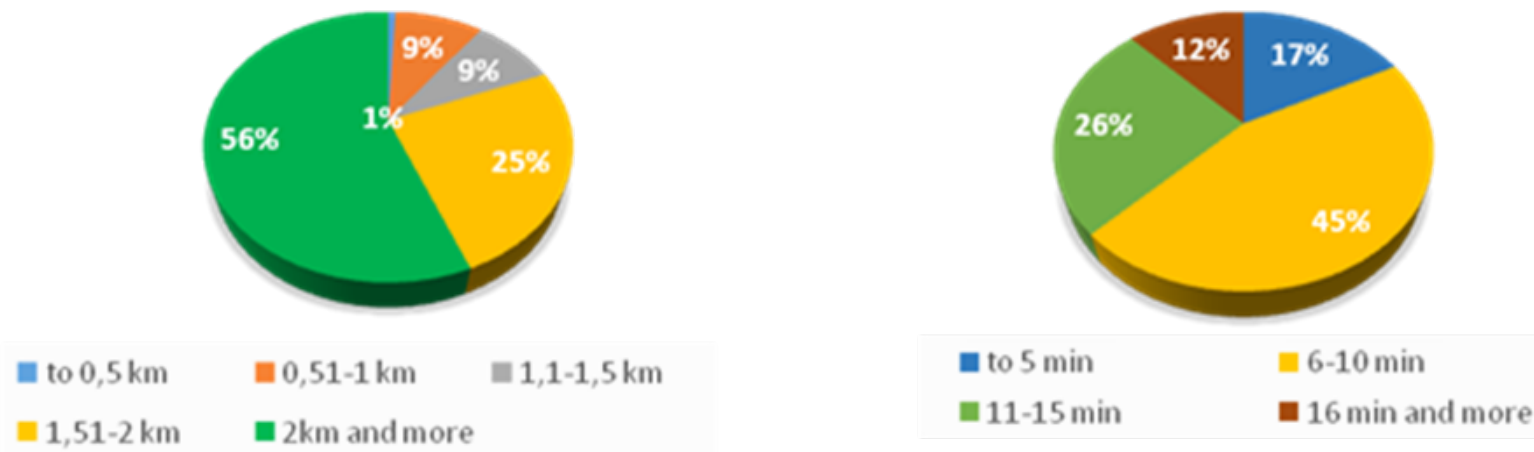

FiguRE 5. Acceptability of alternative route due to the length of detour (left) and with respect to the prolongation of travel time (right). 
more than $2 \mathrm{~km}$ and time accessibility would increase in the interval from 6 to 10 minutes.

Sufficient awareness of drivers concerning road traffic situation is another way how to avoid roads with high intensities, congestions or road sections where a traffic accident occurred. Therefore, when planning the transport, it is appropriate to have the actual current traffic information, which can be detected by the driver before or during the trip through information technologies. According to the survey, the most frequently used means of obtaining traffic information is the radio, as can be seen in Figure 6

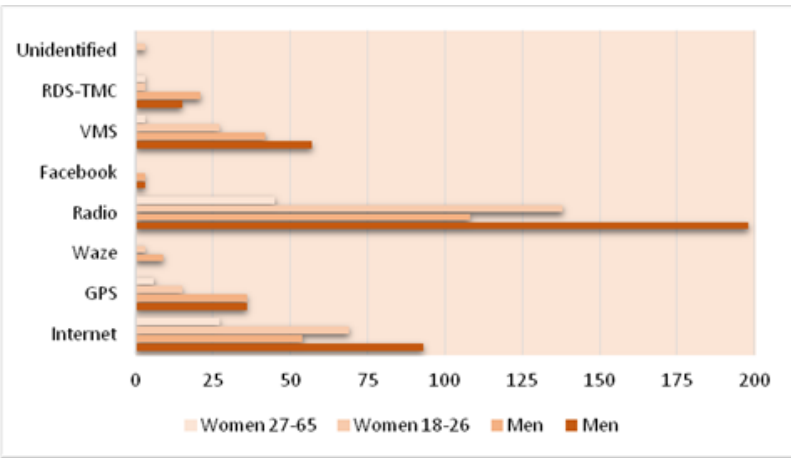

FigURE 6. Information systems used and their share in obtaining traffic information.

In the next question, we asked whether the drivers would appreciate intelligent transport systems, which would alert them about the possible dangers and which of the dangerous situations are the most important to them. The survey shows that women consider the information about black ice and fog to be the most important and the least important are for them warnings concerning dead-end streets. Men consider the information about traffic accident and black ice to be the most important and the least important are for them warnings about dead-end streets and one-way roads. The evaluation scale was as follows: 0 - irrelevant, 1 - the least significant, 5 - the most important. Weighted arithmetic means, which is processed graphically in Figure 7, were calculated based on the values obtained.

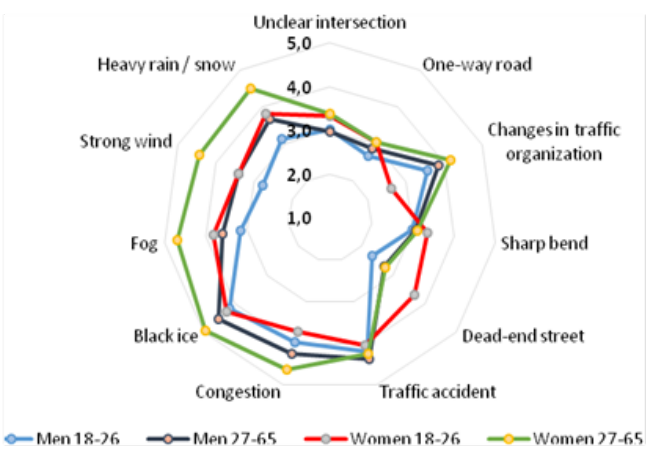

Figure 7. Evaluation of the importance of warning for driver about dangerous traffic situation.
The last part of the questionnaire was devoted to active safety components. It was examined, whether the drivers consider the presence of selected components of active safety to be necessary. Active safety components are defined as systems and devices that help to prevent the occurrence of traffic accidents and thus increase the safety of road transport. Table 4 shows which systems the respondents consider to be the most important. The evaluation scale was as follows: 0 - irrelevant, 1 - the least significant, 5 the most important. The weights of importance were evaluated based on the weighted arithmetic mean.

An overall analysis of the questionnaire shows that the drivers are open to new possibilities of using intelligent transport systems, especially with regards to the increase of their own safety while travelling by a motor vehicle.

\section{Conclusion}

Building telematics technologies is expensive. It is therefore not possible to apply them to all roads. However, they should form an essential part of motorways, expressways and first class roads, mainly because of high traffic intensity on these roads. Several cities, where it will be necessary to solve growing traffic problems by building intelligent transport systems, were chosen, based on the analysis of traffic - transport processes, which was performed within the implementation of the National System of Traffic Information in individual regional capitals and in some larger cities. Sections of road network that pass through the cities of Žilina, Martin and Ružomberok were examined in this paper. These sections have the highest vehicle intensities and it is therefore necessary to solve the traffic issues through the use of intelligent transport systems. Telematics technologies have a positive impact on traffic and its characteristics (intensity, density, speed, etc.) Reduction in the number of traffic accidents can be achieved by reducing the intensity on congested road sections. The use of variable message signs to inform drivers about the current traffic situation and possible obstacles that affect the road capacity appears to be a suitable tool for reducing the risk of traffic accidents. Intelligent transport systems have a positive effect on psychological well-being of the driver while driving. Awareness plays an important role not only in warning about current traffic situation but also in planning the transport before it actually starts. Drivers can check road traffic situation thanks to the topical and real-time information.

Road safety may be improved by reducing the number of traffic accidents and minimize their consequences and thus society can save hundreds of thousands of euros. The main benefit of reducing the number of traffic accidents remains minimization or complete elimination of the negative impacts of traffic accidents on mental and physical aspects of people involved in traffic accidents as well as their relatives. 


\begin{tabular}{|l|c|c|c|c|}
\hline eCall & 3,54 & 3,55 & 4,13 & 3,94 \\
\hline Parking assistant & 1,89 & 2,26 & 2,63 & 3,00 \\
\hline Cruise control & 2,66 & 2,76 & 2,85 & 3,06 \\
\hline Stop \& Go & 1,66 & 1,61 & 2,67 & 2,94 \\
\hline $\begin{array}{l}\text { Automatic system for the detection of con- } \\
\text { gestions }\end{array}$ & 2,86 & 3,11 & 3,35 & 3,88 \\
\hline Lane departure & 2,56 & 3,16 & 3,63 & 3,81 \\
\hline Maintaining safety distance & 3,86 & 2,97 & 3,23 & 3,56 \\
\hline Traffic signs & 2,42 & 2,37 & 2,60 & 3,19 \\
\hline
\end{tabular}

TABLE 4. Evaluation of the importance of active safety systems' application in vehicles.

\section{REFERENCES}

[1] A. Kalašová, J. Palo. Dopravné inžinierstvo organizácia a riadenie. Žilina: EDIS vydavatelstvo ŽU v Žiline, 2003. 162 s., ISBN 80-8070-076-1.

[2] Národný plán SR pre BECEP 2011-2020, July 2014. [online] Available from: http://www.becep.sk/file_download/6/narodny_ plan_sr_pre_becep_2011_2020.pdf

[3] J. Ondruš, S. Kubíková. Interakcia bezpečnosti a inteligentných dopravných systémov. Vedecký recenzovaný online časopis - Svet dopravy, July 2014. ISSN 1338-9629, Available from: http:

//www.svetdopravy.sk/interakcia-bezpecnosti-al -inteligentnych-dopravnych-systemov.

[4] Centrum dopravního výzkumu. Jak lze měřit bezpečnost? [online], Available from: http://www.czrso.cz/clanky/ jak-lze-merit-bezpecnost-1-cast
[5] Road accident investigation guidelines for road engineers, 2007. Available from: http:

//www.who.int/roadsafety/news/piarc_manual.pdf.

[6] M. Sørensen, R. Elvik. Black Spot Management and Safety Analysis of Road Networks - Best Practice Guidelines and Implementation Steps. TØI Report 919/2007, Oslo, July 2014. ISBN 978-82-480-0809-5, Available from: http:

//www.toi.no/getfile.php/Publikasjoner/T\%D8I\% 20rapporter/2007/919-2007/919-2007-nett.pdf. 